Etnográfica

Revista do Centro em Rede de Investigação em

Antropologia

vol. $19(2) \mid 2015$

Vol. $19(2)$

\title{
“These days, it's hell to have boys in France!": emotion management in a French adolescent center
}

"Hoje é um inferno ter rapazes em França!": gestão da emoção num centro francês para adolescentes

Isabelle Coutant and Jean-Sébastien Eideliman

\section{(2) OpenEdition}

Journals

Electronic version

URL: https://journals.openedition.org/etnografica/3986

DOI: 10.4000/etnografica.3986

ISSN: 2182-2891

\section{Publisher}

Centro em Rede de Investigação em Antropologia

Printed version

Date of publication: 1 June 2015

Number of pages: $229-246$

ISSN: 0873-6561

\section{Electronic reference}

Isabelle Coutant and Jean-Sébastien Eideliman, "“These days, it's hell to have boys in France!": emotion management in a French adolescent center", Etnográfica [Online], vol. 19 (2) | 2015, Online since 19 June 2015, connection on 11 February 2022. URL: http://journals.openedition.org/ etnografica/3986 ; DOI: https://doi.org/10.4000/etnografica.3986

\section{(c) (†) 8}

Etnográfica is licensed under a Creative Commons Attribution-NonCommercial 4.0 International License. 


\section{"These days, it's hell to have boys in France!": emotion management in a French adolescent center}

\section{Isabelle Coutant and Jean-Sébastien Eideliman}

How do contemporary health policies, especially those concerning the mastery of emotions in the psychiatric sector, weigh on individuals? Based on fieldwork in an Adolescent Center in a disadvantaged Parisian suburb from January 2010 to March 2011 , this article analyses what these institutions reveal of and contribute to the fabrication of individuality in western societies. In these institutions at the crossroads of psychiatry and social work, the management of emotions appeared to be a useful tool for analyzing the transformation of power over individuals at the bottom of the social ladder, especially immigrants. Our analysis shows how the effects of this work are ambivalent, and vary according to gender and social trajectories.

KEYWORDS: psychiatry, gender, immigration, emotion work, shame, France.

"Hoje é um inferno ter rapazes em França!": gestão da emoção num centro francês para adolescentes - Como pesam sobre os indivíduos as políticas de saúde, especialmente as relacionadas com o domínio das emoções no setor psiquiátrico? Com base em trabalho de campo realizado de janeiro de 2010 a março de 2011 num centro para adolescentes de um bairro desfavorecido nos arredores de Paris, o artigo analisa o modo como estas instituições revelam e contribuem para a construção da individualidade nas sociedades ocidentais. Nestas instituições, situadas na interseção da psiquiatria e do serviço social, a gestão das emoções parecia ser um instrumento útil para analisar a transformação do poder sobre indivíduos nos escalões sociais mais baixos, especialmente os imigrantes. Esta análise mostra como os efeitos deste trabalho são ambivalentes e variam segundo o género e as trajetórias sociais.

PALAVRAS-CHAVE: psiquiatria, género, imigração, emoções, vergonha, França.

COUTANT, Isabelle (icoutant@ens.fr) - CNRS, Iris, France.

EIDELIMAN, Jean-Sébastien (jean-sebastien.eideliman@univ-lille3.fr) - University of Lille 3, CeRIES, France. 


\section{INTRODUCTION}

The 2005 riots in France drew worldwide media attention and provoked a wide range of discourse. ${ }^{1}$ Sparked by the deaths of two teenage boys who took refuge from the police inside an electrical transformer, the riots were a link in the chain of recurring urban violence in the peripheries of large cities since the early 1990s but were more striking in their scale, both geographically in how they spread across the country, and temporally in terms of how long they lasted. Although the rioters were not all of immigrant descent, cartography of the riots shows that they occurred in neighborhoods sheltering the most recent waves of migrants, where large families of sub-Saharan African origin were over-represented (Lagrange and Oberti 2006). In France as elsewhere, commentators blamed the failure of the French model of integration, accused of being rigidly stuck on a republican conception of the nation that, by denying differences, hid discrimination (Jobard and Névanen 2009). Some observers noted that there was relatively little vandalism and that, with the exception of burned cars, rioters targeted symbols of the State in all its forms - in addition to local National Police headquarters, rioters damaged schools, municipal gyms, and libraries (Lagrange and Oberti 2006) - as if the youth engaged in these events had simultaneously wanted to express their anger at being the target of incessant police controls as well as the educational system's unkept promise of integration.

And so, like in the late $19^{\text {th }}$ century, the "social question" returns to prominence, renewing Durkheimian concerns for the quality of social relations and the risks of dissociating populations whose oppositions seem increasingly irreducible: poor and rich, young and old, Catholic and Muslim, French and foreigner. One of the special features of this new social question is that it specifically concerns youth from working-class neighborhoods peripheral to city centers (the banlieues). The most visible reaction came from the legal front, with increasing criminalization of juvenile delinquency (Bailleau 2009), but in social and educational institutions the issue takes other forms. Fears that troubled teens might become violent prompted incentives for opening listening spaces. Specifically moral issues (the unacceptability of teen suicide) thus got blended with more specifically political issues (the management of public order), which relate back to socially differentiated populations: behavioral problems (always thought to lead to delinquency) for the most part affect lower-income boys, while suicide attempts are mostly made by girls from a range of social backgrounds. The division between victims and perpetrators that has been promoted by the repressive policies of the last decade has allowed for 
the surreptitious reintroduction of distinctions of gender and class, with boys from the banlieues increasingly being cast in the role of perpetrator (Coutant and Eideliman 2013).

The psychiatric sector has seen some particular developments that provide good examples of the ambivalent qualities of policies trying to combine benevolent listening with social control. As so many have shown (notably Foucault 2006 [1961], and Barrett 1996), contemporary psychiatry as a site of work on individual normality is in a state of major and uncertain upheaval, its range of application being broadened as its expertise is diluted when it fades into a grey area shared with other professions on the edges of the medical and social fields (Ehrenberg and Lovell 2001). Absorbed into the new field of mental health, psychiatry saw its patients transformed into "clients" and its objectives go from healing mental illnesses to the improvement of nearly everyone's psychic well-being. Hereafter integrated into a great variety of institutions, psychiatry is present, for example, in the new adolescent centers (Maisons des adolescents) that we chose for our research. These are public institutions created in the early 2000 s at the intersection of social work and psychiatry. Between January 2010 and March 2011 we conducted observations of counseling sessions and team meetings twice a week and interviewed professionals, adolescent clients, and members of their families all associated with one adolescent center, located in an underprivileged town in metropolitan Paris. Given its geographical location, the center we studied serves predominantly working-class families, most of them immigrants.

A significant portion of the work done in this center consisted of making adolescents, and even more so parents, acknowledge affects (anger, sadness, shame...). Many institutions have seized upon the notion that speech heals and self-knowledge emancipates, making it common ground and the basis for how they intervene. In the studied adolescent center, professionals find this "pedagogy of reflexivity" (Coutant 2012) especially useful because their young clients tend to accumulate attributes distinctive to dominated categories of people (their young age, working-class backgrounds, and immigrant backgrounds), making them less predisposed to take themselves this reflexive approach to their difficulties, let alone their emotions. The last of these attributes is given particular attention because the center relies heavily on the ethno-psychiatric approach that holds that migration produces trauma by causing ruptures in familial transmissions that should be put into words.

Psychologists (Lewis 1971) and sociologists (Scheff 2000) have been interested in the acknowledgement of emotions, especially its beneficial effects for the individual and society at large. We propose building on and enhancing their work by showing how these effects vary and take on different meanings depending on the social processes around them. We hypothesize that patients' characteristics (gender, social background, social trajectories, and migratory 
paths) have a significant influence on their reactions to the injunction to express their emotions.

We will start by describing the workings of the studied organization, which is faced with situations where social and psychic difficulties are often intimately intertwined. Certain social and migratory trajectories, which we will explore more deeply in the following section, produce particular sentiments of shame and humiliation themselves. In conclusion, we will see that the handling of these situations leads to differing consequences depending on the gender and life course of the adolescents coming to the center.

\section{AN INSTITUTION UNDER TENSION}

Formed in response to new injunctions for professionals to work in networks and provide a place for expressing individual suffering, adolescent centers appear to be echo chambers of problems encountered by the other institutions (like schools and child protection organizations) that turn to them in desperation. Their objectives are to guide and comfort the adolescents they take in, as well as to reassure and support other institutions struggling with difficult or distressed adolescents. Like the mental health sector as a whole, adolescent-center professionals are increasingly faced with situations where social and psychic problems overlap, to the point of having difficulty building therapeutic alliances based on anything other than a request for social assistance.

\section{Missions that are difficult to reconcile}

The youth center we studied, headed by a psychiatrist, was created in the early 2000s and served young people aged 12 to 21 . It was intended for adolescents "with psychological or psychiatric problems, or who are at risk," excluding acute crises or psychiatric emergencies. A variety of "pathologies" are listed in the intern handbook: attempted suicide, depression, speech disorders, eating disorders, nervous disorders, school phobias, family crisis situations, difficulties related to immigration status, dropping out of school, drug addiction. The center begins counseling with some initial interviews (three on average) during which a team (often comprised of a psychologist or psychiatrist and a social worker) assesses the situation. More detailed follow-up may then be offered - individual counseling, family counseling, workshops, relaxation - in a dynamic favoring a psychoanalytic and/or cross-cultural psychiatric approach in the significant number of cases where clients come from immigrant families.

The youth center professionals are charged with untangling complex situations in which family conflict, social (and sometimes legal) instability, cultural distance, and academic underachievement may all blend together. 
A social worker we met felt that it is often adolescents' living conditions that make them "go nuts." She spoke of families "torn apart by insecurity." According to INSEE data, over $50 \%$ of housing is public housing in the city where we conducted our study. In 1999, 33\% of its population came from countries other than France, 30\% had not graduated from high school, 22\% lived in single-parent families, and 38\% were under the age of 25. According to income tax records, in 2004, half of the city's households did not earn enough to be subject to taxation. In 2006, the unemployment rate hovered around $20 \%$.

Referrals often come from other institutions under pressure, usually the school system and, to a lesser extent, child welfare. Even when teenagers or parents contact the center themselves, it is frequently because they had been referred by someone from one of these institutions. Professionals at the center sometimes felt that adolescents mainly suffered from institutional mistreatment, be it the "failure" of social and educational services or the "brutality" of the school system. The psychiatrist in charge of the facility we studied claimed to be mindful of the risk that schools might exploit his service, which would only reinforce the stigma that the child already carries. As an Algerian immigrant who had fled the violence in his country in the 1990s and descended from marabouts in a small Kabyle village, he was trained in cross-cultural psychiatry and was particularly attuned to the backgrounds and situations of immigrant families. He believed that the whole point of the institution was, paradoxically, to "de-medicalize this period of life." To avoid further stigmatizing adolescents, he saw his work as partly resisting other institutions' demands whenever they seemed inappropriate.

Consequently, comforting both adolescents and the institutions that sent them to the center could sometimes prove contradictory, because the center's professionals feel that responding to institutional demands may sometimes go counter to pursuing adolescents' improved well-being.

\section{A surprisingly easy research process}

After some initial reservations, our proposal to conduct research in the adolescent center was ultimately well received. We were not only able to conduct observation and interviews as we intended, we were even partially integrated into the care team during family counseling. We will detail the material that these research methods allowed us to collect, but first of all we wish to discuss the relative ease with which we were able to operate and what we might learn from it.

There are three main arguments that might explain our being so well accepted by the center. The first is its wide multi-disciplinary mix (social workers, psychologists, nurses, pediatricians, and psychiatrists collaborate on a daily basis) and the predominance of psychoanalytic and ethno-psychiatric 
theoretical approaches. A variety of professionals thus seemed to forget their particular professional specialization regularly, positioning themselves on psychotherapeutic analysis. The presence of sociologists is not incongruous in such a setting, and given the considerable connections between the social sciences and ethno-psychiatry we were expected to contribute to group discussions. Secondly, the center's doctors were also university-affiliated researchers, and as such saw themselves as colleagues comprehensive of the constraints of conducting research and even eager for scientific discussion with us. Lastly, this center was in a particular moment in its history, going through an institutional crisis after a period being a pioneer in its domain. In the years leading up to our study it had become overshadowed by the adolescent center of Paris, which had become much more prestigious and drew considerable media coverage and for which this center's previous director had left shortly before we began our study. Our study could certainly have been perceived as a threat during difficult times, but it seems instead to have been seen as a way to give new luster and visibility to the work carried out there.

This ready access to our research site seems revealing of both developments in the mental health field and the particular position held by institutions such as the adolescent center we studied. Sociologists may be seen as experts and allies in such institutions, which are dominated within their field both because they are situated in marginal geographical and social zones and because they treat difficulties that are challenging to classify in psychiatric nosology, since they combine psychological and social problems. Sociologists are allies because they reveal the mechanisms of domination to which these institutions' professionals are victim (Bourdieu et al. 1999 [1993]) and because they seem to have the potential to support their legitimacy and raise recognition with their description of professional practices. This alliance between "psych" professionals and representatives of the social sciences is likely facilitated by the recent development of the field of mental health, which altered the balance between the disciplines of reference (Elias 1969). The declining influence of psychoanalysis and some psychodynamic approaches in favor of cognitive and biological sciences may lead the former to see the social sciences as allies that, like them, find the environment and life histories determinant in behaviors and feelings.

Over the course of the study, we followed the experience of a selection of families from the consulting room to their homes, via the offices of implicated professionals, the adolescents' secondary schools, and other institutions involved in keeping track of their situations. This allows us to back up this article's analysis with some detailed case studies, which are obviously only a small part of the findings used in the overall analysis. Our material consists of observations of approximately forty family counseling sessions, twenty-odd 
team meetings and as many interviews with adolescents and/or their families conducted outside the centre (usually at their home), besides twenty interviews with various professionals in contact with the adolescents we met. This data was supplemented by the study of medical files.

This research protocol raises some important deontological issues. Naturally we requested and received numerous authorizations (from the people we met, the institutions we visited, and ethics committees internal to the world of research), but we also gave considerable thought, jointly with the person in charge of the adolescent center, to how we might best proceed to minimally disrupt therapeutic relationships. We were thus unable to attend individual counseling sessions, and were limited to family counseling where we joined the panel of co-therapists greeting families. It was agreed that we could not be pure observers, because families might be unsettled by the presence of people who never speak or participate, and in fact we had little trouble contributing during sessions because discussions were conducted in a way not dissimilar from sociological interviews: the adolescent's parents were asked to describe their life-courses and how their relationship with their child had developed through the years. These transcultural family counseling sessions are essentially designed to get the adolescent to hear their parents' migration story from their own mouths, to introduce continuity into the adolescent's own history, and to shed light on grey areas. We will now use an observed session to illustrate how center professionals work, especially how they give such importance to the expression and acknowledgement of emotions, which might seem overwhelmed by materially difficult living conditions.

\section{Foraging for emotions}

Mrs. Orélien ${ }^{2}$ comes to her family's first transcultural counseling session with two of her daughters, Gladys, born in 1990, and Elaine, born in 1993 (her four other children live in the United States and Haiti). Guided by the psychiatrist's questions, she tells the story of their illegal migration from Haiti (where she had been a vendor) to France in 2006. After her husband abandoned her, worried about her daughters' health, she had seized an opportunity to go to France on a short-stay visa. She had Elaine come over as soon as possible, paying 6,000 euros to a man who passed her off as one of his own daughters, two years younger; an acquaintance helped her bring Gladys over with a similar strategy, making her out to be four years younger. Lodged in insecure conditions with the people that had helped them migrate, educated under assumed identities and ages, both girls develop problems that end up attracting the 
attention of school employees: Gladys falls into depression, and Elaine threatens suicide.

At the debriefing following their first session, the therapist is uncomfortable. The socio-economic problems, he believes, are too significant for a real "therapeutic alliance" to be put in place. Mrs. Orélien incessantly asks them to help with their material situation. The therapist interprets the invoked psychological problems more as the somatization of their socio-economic insecurity than as genuine psychic disturbances that a psychotherapist could treat. The second session provides another opportunity to further explore the women's material and social problems, and as usual the therapist cites the affects he observes, evoking the mother's sadness, but also her courage. In reaction, instead of replying Mrs. Orélien intones a Haitian resistance song, then explains its meaning to the transfixed team. After the session, the psychiatrist brings up this episode with a smile, concluding, visibly comforted, "It works well, in the end!" To take up the terminology he used in our first interview with him, "foraging" finally allowed them to get to emotions: "In all psychotherapy, obviously the basic, if not indispensible, ferment, the essential, it's emotions. When there's no access to them, you can't do much, but it's also case-by-case. Yes, it's our fuel, but you have to find it. Sometimes, even when you're trying to forage for a long time, and you're trying to go further, it doesn't work, you don't feel anything at all." Indeed Mrs. Orélien's song has the ring of a sort of therapeutic ideal: the transfigured expression, charged with affects, of suffering and will.

Adolescent centers are thus institutions in a difficult position, torn between a mission of social control and a therapeutic ideal, itself often inspired by psychoanalysis, that is difficult to implement given the limited time and means at their disposal. When, on top of that, they are faced with publics combining psychic and social problems, their task only becomes more arduous.

\section{TRAJECTORIES OF SHAME}

Among the emotions family counseling "works on," shame holds a significant place. A number of factors may provoke this particular feeling, which some consider to be the most social of emotions (Scheff 2000). Over the course of our study, it seemed to us that the handling of shame was particularly revealing of the entanglement between psychic and social processes that the adolescent center professionals tried to separate from each other as much as possible.

\section{Humiliated parents}

During a transcultural counseling session, Hamidou's father tells of the humiliation he felt when he was called to the middle school because of his 12-yearold son's "behavior problems." He had the impression of finding himself in 
"court," and he felt demeaned: "they were spitting on me," "I was on the ground," he says. The terms "humiliated," "humiliation," and "honor" appear again and again in this session: "It's as if I was good for nothing." The family has lived in a public housing project for a short time and the father dreads his children "falling in with the wrong crowd." He is also worried about juvenile norms for relations between the sexes: "I'd rather die than see my son caught up in some sex situation, it's dishonorable." He is quite fearful his son will "lose his honor." He straight out admits to the center's professionals that he had envisaged sending his son to Guinea to protect him from a potential fall into delinquency. Then, seizing the opportunity all the questions provide, he comes back to his life story, recounting that he had been educated up through high school in his country. He said that he would have liked to have continued his studies if he hadn't been hindered by the need to help out with his father's business. He confides all the hopes placed on his only son, who disappoints him terribly, while his six daughters cause no problems and do well in school.

Although immigrant parents express their distress in terms of their children, they may also feel humiliated by French institutions due to some aspects of their children's behavior, as Hamidou's father describes. Immigrant fathers base the legitimacy of their presence in France on work and submission to the norms of the host society. They do not necessarily see themselves in these "children of France," "these children who don't carry on the parents" (Sayad 1979a, 1979b), because of the children's acculturation into their host society. This explains the nagging anguish when they find themselves unable to give credible meaning to their immigration. This may happen after a work-related accident, for example: French professionals of the psyche have long used the category "sinistrose" to designate the psychic disturbance prompted by these situations of forced inactivity (Sayad 2004), referring to a fall into abject hopelessness. One might hypothesize that for immigrant parents, this might also occur when a child's deviance at least partially cancels out the family's plans for ascension that motivated its migration, all the more so as its reputation in its community is quickly tarnished by a child's deviance. Families usually have high expectations for their children's success in France. If in theory educational democratization offers identical prospects for all students, in practice, socio-cultural handicaps weigh on individual fates. Boys in particular struggle to satisfy family expectations, and those who are socialized in street culture deal with institutions other than schools: the police, the justice system, social work (Fassin et al. 2013). But these parents fear that in using their traditional child-rearing methods, which include physical violence, they will be pulled into the French justice system, which promotes other norms of childhood protection. Some fathers express their impotence and threaten to return children to the family's country of origin as the only solution (Timera 2002). As in the 
United States (Kane 2011) and other western European countries (Bledsoe and Sow 2011), parents see sending boys back "home" as an alternative to legal detention.

\section{"Illegitimate" children}

Shame is found elsewhere on the children's side of the equation. When social mobility leads to an imbalanced habitus, it may engender a feeling of shame arising from the impression of a gap between real and virtual identities (Goffman 1963). This may be the case in paths of social ascension with or without migration. Annie Ernaux, a French writer, devoted one of her books to shame: from a working class background, she evokes her shame at school when in contact with girls from bourgeois milieus (Ernaux 1998 [1997]). She says that her feelings of illegitimacy stemmed from her unfamiliarity with the legitimate culture so valued by the educational institution, and also describes her disgust for certain aspects of the social milieu she came from and the distance that gradually separated her from her parents. In a chapter of The Weight of the World, Pierre Bourdieu (1999 [1993]) devoted a short text to these ambivalences that children of the working classes in social ascension may feel: guilty of disappointment if they fail, guilty of treason if they succeed. It is in this sense that Bourdieu speaks of "contradictions of inheritance," an expression giving title to an article referring to the idea of the "double bind": "Do better than me, but stay like me." This injunction is perhaps even more pointed for children of immigrant backgrounds, especially in post-colonial societies (Probyn 2004). How to reconcile familial attachment and respect for a culture of origin with a juvenile socialization that quite often transmits other norms that may come into conflict with those of the parents? Parental respect and attachment do not prevent young people from seeing their parents as "backward," "out of date," "like back in the village," whether in juvenile in-group contexts or the intimacy of a therapeutic session or interview with counselors or sociologists.

When the children do well in school, they grow even farther from their parents and may find themselves in awkward situations that are conducive to shame. Jennifer, the youngest in a family of five children (all born in Kabylia except for herself, born in France) came to the adolescent center following anxiety crises and suicide attempts. The psychiatrists also mention a "split" functioning in her file, something she seems to pick up on when she speaks of herself. Jennifer is a very good student. She hopes to pursue higher studies in law, but is as anxious about encountering Parisian students as she is about leaving her mother alone, since her parents live essentially as a separated couple. She is aware of the distance separating her from legitimate culture on one side and her family on the other, but she does not talk about her gnawing doubts with her siblings because "they don't understand." She feels 
different. Not only is she the only one born in France, she is the only one to have obtained the baccalaureat, an examination-based degree that caps the end of secondary studies and opens the way to higher education. Light-skinned and very western in appearance, she contrasts physically with her mother, who wears traditional clothing and a headscarf, and speaks in Kabyle. Over the course of her counseling, it seems that her troubles are not unrelated to her ascendant trajectory and the geographical and symbolic rupture that it portends.

Conversely, children who disappoint parental expectations and are not up to the role cast for them in the family's plans may also feel ashamed, but for the opposite reasons: they ought to be more than they really are, and their self-image does not match their parents' perceptions or aspirations. The father of Kevin, who is from the Comoros Islands, confides in the adolescent center professionals: "My parents work in sugar cane. Me, I want Kevin to climb to a certain level. If he doesn't take the right path, I should set him straight." These children are often anguished when the school system orients them toward paths of study they feel are degrading, even when their parents, unfamiliar with the complexity of the French educational system, do not understand the significance. This most often means being oriented toward a vocational high school instead of an academically oriented one or having a vocational option imposed without being given the choice, in an institutional rationale of distribution based on the number of places available in various sections. Our observations show that sometimes such orientational problems alone can bring people to the adolescent center. In the case of an adolescent named Sarah, her anxiety crises worsened when she was oriented into a special class for challenged students, which she experienced as demeaning but her parents accepted without understanding what was at stake. She expressed her distress in multicultural counseling, her shame of being mixed up with handicapped youths and her anger at her father who, although he had high hopes for her, approved the educational team's proposed orientation. In another case, an adolescent boy, initially in counseling because of parental concern about his video-game addiction, ended up admitting that he had been demotivated by his orientation toward a vocational high school when he had wanted to attend a general high school (to which he would eventually be reoriented).

Shame is thus a particularly complex emotion that easily combines social and psychic dimensions. Adolescent center professionals' work partly consists of emphasizing the psychic dimension with adolescents and their families, while minimizing the role of social causes, over which they also have less power. 


\section{HEALING THROUGH ACKNOWLEDGEMENT}

Generally speaking, beyond the diversity of cases, the work conducted in adolescent centers may be analyzed both as an activity of mediation (between parents and children, between families and institutions in charge of youth) and one of affect and emotion management (Martin 2000). It is a matter of doing "emotion work" with families (Hochschild 1979). So what are the principles and consequences of this work with socially heterogeneous populations?

\section{Acknowledging shame}

In the transcultural counseling we attended (and participated in), the moral work largely takes place by legitimating the expressed emotions and naming presumed emotions. On these occasions, the therapist regularly reminds those present that "anything can be said" in such a setting: "You can say what you want here," "it's very important that you get things out, this is the place for these things to happen," "this is the place to dump things that hurt," and so on. Over the course of the counseling, alongside references and/or expressions of shame, therapists verbalize the underlying anger they suppose plagues at least the fathers. They are encouraged to acknowledge it in order to escape it: "It's like a seed, anger - when you bury it..."; "You know that anger can hurt the people around you?"; "What can be done to get rid of all this anger?"

The search for the acknowledgement of affects in general, and shame in particular, has its full place in classic psychotherapeutic practice, especially in the psychoanalytic vein, although the ethno-psychiatric setting gives it a specific connotation here. Psychoanalysts such as Helen Lewis (1971) think it is essential to acknowledge shame so that it does not turn into frustration, humiliation, or uncontrollable anger. Lewis believes that recognizing shame puts a virtuous cycle into motion in counseling; as a therapist she herself believes she under-estimated the importance of these issues for a long time before becoming aware of this term's omnipresence while analyzing recorded interviews. Psychoanalysts aren't the only ones to formulate such hypotheses: sociologists (Ryan 1993) and anthropologists have developed very similar theories; Thomas Scheff (2000) is notable among them, basing himself heavily on Lewis's work to highlight the importance of the acknowledgement of shame in his own work. Starting from an impressive review of the sociological literature, citations spanning Georg Simmel, Norbert Elias, Richard Sennet and Erving Goffman, he adds the idea that the non-acknowledgement of shame comes to directly weaken social bonds to which he believes it is intimately linked. He consequently believes that non-acknowledged sentiments of shame bring about violence, going so far as to account for Franco-German relations from the late $19^{\text {th }}$ to mid- $20^{\text {th }}$ centuries in such terms, whose dramatic opposition represented a sort of paroxysm in the destruction of social bonds. He then 
pleas for acknowledgement of the humiliations that were exercised and suffered, at the individual as well as State levels.

Without wishing to challenge these mechanisms' psychological and anthropological significance, from a purely sociological perspective we think it worthwhile to resituate these theories back into the context that produces them: societies where responsibility, autonomy, and reflexivity have become cardinal values by which we judge adult individuals. In this context, requiring the acknowledgment of emotions also functions as an injunction to reflexivity to which some individuals can adapt much better than others, depending on whether their socialization prepared them for such reflexive contemplation of their practices and feelings.

\section{Acknowledging shame, or arousing it?}

The professionals' challenge is to get families to verbalize their affects, but without shaming them by their intrusion. Even if the professionals have the deeply held intent of not judging parents, one of the process's objectives is to lighten the stigma borne by the child by shifting the weight of the intervention onto the parents, who are in a way summoned to explain themselves, or at least to talk about themselves in front of their children. Although the shame parents sometimes feel when in contact with French institutions (school, courts, police, social work) may be acknowledged in counseling, the counseling process may in turn produce other uncomfortable feelings that can feed into a sentiment of humiliation. Case in point, Mme Orelien's youngest daughter Elaine, whose situation we presented earlier, stopped coming to counseling because it was too upsetting to lay out family problems in front of strangers, "as if she were ashamed to hear talk about her father, our worries, etc.," as her mother put it in an interview. Kevin's mother, an immigrant from the Comoros, was unsettled by family counseling: she found herself face to face with her ex-husband, who she had left several years earlier. Before being able to give her point of view (about her arranged marriage and her oppression by her in-laws), she had to listen to Kevin's father's complaints and accusations in front of a panel of a dozen people, which ultimately caused her to withhold most of her version of the facts. The processes itself is, if not humiliating, at least quite intimidating.

Hamidou's parents and Kevin's mother were not truly ashamed during their visits to the center, but they did not feel entirely cleansed of the everyday humiliations they suffer through the school and their insecure living conditions, either. This indicates that shame may touch on different issues for participants on either side of counseling. At the individual level (generally the focus of therapists' attention), shame is the opposite of pride or self-confidence, of psychic well-being. On a collective level, where it approaches humiliation, it is more in opposition to honor, a structuring category in many Mediterranean societies (Herzfeld 1980; Peristiany 1965), especially in the working classes. Seeking 
to revive an honor thought besmirched, the adolescent center responds with a reflexive pedagogy aiming to bring out feelings of shame or anger. In this space between shame and humiliation, honor and self-acceptance, tensions and incomprehension may emerge, making the emotional work particularly difficult.

\section{Different effects depending on gender and trajectory}

Overall, the institution indeed seems to have helped the adolescents develop a higher sense of worth, for their families and in their own eyes. Girls who are doing well in school and have plans for social ascension may invest themselves even more in the place, using it simultaneously as a pretext for this ambition, as a tool to distance themselves from the family, and as a means to acquire self-management skills. Jennifer follows the counseling offered at by the adolescent center because she finds it to be a space "for herself," and she manifests an interpersonal relational style and a particular relationship to language coming from the higher classes to which she aspires. The institution in a way offers her the opportunity of doing self-transformation work (Darmon 2009) and allows her to express her emotions at this time of her life. In these cases, relations with social work and psyche professionals contribute to the acquisition of emotional skills, a communicational capital (Schwartz 1998). Gladys, Elaine's sister, took up the counseling process in the same perspective: she would like to become a psychologist. Before coming to the adolescent center, she was suffering from both a downward scholastic slide related to her false identity and from another form of shame because her professional goals didn't match the hopes of her mother, who associates seeing psychologists with insanity. At the time we met, Gladys seemed to have found a compromise by preparing herself for the nursing school entrance exam while taking advantage of her individual counseling at the adolescent center to better understand and assume her "difference" and to acculturate herself to the professional culture that attracts her (Coutant and Eideliman 2013).

To the contrary, some boys are reticent to participate and may even reject the adolescent center. When we telephoned an adolescent named Karim to ask if he would be willing to meet with us for a sociological interview following the conclusion of his counseling, he replied coldly: "No, I'm not interested, I'm not crazy." Another boy, Gonzalez, refuses to participate in transcultural counseling. In one meeting he loses his temper when the therapist asks his mother about her dreams, denouncing it as an intrusion and an additional form of humiliation that goes against formally declared intentions. He rises roughly and storms out, slamming the door and leaving the professionals ill at ease. The psychiatrist asks whether the boy had been forewarned of the collective format of the counseling, aware of the potential violence such a procedure might have for someone taken unawares. 
Girls' and boys' differing attitudes toward the program give particular resonance to a heartfelt exclamation Hamidou's father's made during an interview at their home: "These days, at the dawn of the millennium, it's hell to have boys in France!" The mass of data attesting to the existence of masculine domination (Bourdieu 2002 [1998]) seems to prove him wrong. Yet when it comes to scholastic matters, for the last 30 years girls have been on par with or even surpassed boys: they pursue education further, even if the most valued programs are still overall dominated by boys (Baudelot and Establet 1992). In general, a number of structural social transformations giving increasing weight to cultural capital over economic capital in the construction of social trajectories have contributed to a new appreciation for attitudes that might be qualified as feminine, in that they are more traditionally associated with women than men due to socialization: being a good listener, having relational sense, being able to express one's emotions. From this point of view, might not the policies informing the adolescent center's actions - talking about oneself, bringing up the past, analyzing relationships with parents - show over-sensitivity or even weakness? Isn't it better to "suck it up and deal," to use a very common masculine expression, and "forge ahead?" Policies of listening - which are moreover deployed in institutions often labeled "homes" (maisons, as in these Maisons des adolescents) in reference to the feminine domain par excellence, the domestic sphere - play on aptitudes that, although not reserved for a particular population category, are more frequently developed and assumed by women, and those of the middle and upper classes in particular. The emotional work deployed in State-supported institutions sketches out an individuality that contrasts sharply with the models that guide the socialization of boys in working-class milieus.

\section{CONCLUSION}

How do contemporary policies of the intimate (Berrebi-Hoffmann 2009), especially those concerning the individual mastery of emotions, weigh on individuals today? From a Foucauldian perspective, one could point to new forms of social control coming from institutions at the crossroads of psychic and social works. From a Marxist perspective, one might denounce the hypocrisy of mechanisms that re-enforce the neoliberal order by legitimating it (Sundar 2004). Starting from specific situations and how they were handled in an adolescent center located in a disadvantaged suburb of Paris, we wanted to take the time to focus on what these admittedly ambivalent mechanisms reveal and what influence they might have on the construction of individuality in western societies today. The management of emotions proved to be a precious vantage point for analyzing the transformation of power over individuals. Such power is ambiguous and complex because, although it doesn't necessarily work 
against individuals, it can still weigh on them, sometimes with their consent or even investment, with different consequences depending on the individual, one's characteristics, and the configurations one is embedded in.

Even more than weakness in the social bond, the expressions of shame we recounted from the adolescent center seem to us to be fundamentally linked to a mismatch between virtual and real social identities, themselves caught up in the interplay between trajectories and anticipation, which leads to thinking about identities in a collective, especially familial, dimension. Adolescent centers, like so many other institutions based on a pedagogy of reflexivity, try to get clients to admit their emotions to release tensions and help individuals respond to the injunction to "be themselves": the soul-searching and dredging up of the past should allow people to project themselves more easily into the future and transition from adolescence to adulthood successfully. Yet the consequences of this work are mixed because, depending on their trajectories, individuals may be able to follow these injunctions with ease, or they may struggle to do so. The most resistant are boys, with the greatest social and cultural distance from the dominant (which in this setting are incarnated by psychiatrists, among others). It must be said that these policies are imbued with more feminine and intellectual values than the repression-based policies they compensate for or complement.

These results allow us to understand the difficulties some families, especially immigrants and those living in difficult socio-economic conditions, face in satisfactorily raising their children (especially boys) to an adulthood of autonomy, responsibility, and social recognition. Their child-rearing norms put into question, challenged by the gap between their social ambitions and their living conditions, they are also tested in institutions that have a tendency to psychologize and culturalize their difficulties by rapidly removing social determinants from the discussion. This state of affairs certainly shows the power of the culturalist paradigm, but it is also the product of societies where economic difficulties curb structural actions addressing social inequalities. Through their work on emotions, adolescent centers do provide non-negligible support for ascendant trajectories, but doubts about their effectiveness in preventing the new uprising against public and moral order called for by many heavily dominated marginal groups are justified unless people are given the material support needed to set them free. 


\section{REFERENCES}

BAILLEAU, Francis, 2009, "La France, une position de rupture? Les réformes successives de l’ordonnance du 2 février 1945”, Déviance et Société, 33 (3): 441-468.

BARRETT, Robert J., 1996, The Psychiatric Team and the Social Definition of Schizophrenia: An Anthropological Study of Person and Illness. Cambridge, Cambridge University Press.

BAudelot, Christian, and Roger ESTABlet, 1992, Allez les filles! Paris, Editions du Seuil.

BERREBI-HOFFMANN, Isabelle (ed.), 2009, Politiques de l'intime: des utopies sociales d'hier aux mondes du travail d'aujourd'hui. Paris, La Découverte.

BLEDSOE, Caroline H., and Papa SOW, 2011 , "Back to Africa: second chances for the children of West African immigrants", Journal of Marriage and Family, 73: 747-762.

BOURDIEU, Pierre, 2002 [1998], Masculine Domination. Stanford, CA, Stanford University Press.

BOURDIEU, Pierre, et al., 1999 [1993], The Weight of the World: Social Suffering in Contemporary Society. Stanford, CA, Stanford University Press.

COUTANT, Isabelle, 2012, Troubles en psychiatrie: Enquête dans une unité pour adolescents. Paris, La Dispute.

COUTANT, Isabelle, and Jean-Sébastien EIDELIMAN, 2013, "The moral economy of contemporary working-class adolescence: managing symbolic capital in a French public 'Adolescent Centre'”, British Journal of Sociology, 64 (2): 248-266.

DARMON, Muriel, 2009, "The fifth element: social class and the sociology of anorexia", Sociology, 43 (4): 717-733.

EHRENBERG, Alain, and Anne M. LOVELL (eds.), 2001, La maladie mentale en mutation: Psychiatrie et société. Paris, Odile Jacob.

ELIAS, Norbert, 1969, "Sociology and Psychiatry", in S.H. Foulkes and Stewart G. Prince (eds.), Psychiatry in a Changing Society. London and New York, Tavistock Publications, 117-144.

ERNAUX, Annie, 1998 [1997], Shame, New York, Seven Stories.

FASSIN, Didier, et al., 2013, Juger, réprimer, accompagner: Essai sur la morale de l'Etat. Paris, Editions du Seuil.

FOUCAULT, Michel, 2006 [1961], History of Madness. New York, Routledge.

GOFFMAN, Erving, 1963, Stigma: Notes on the Management of Spoiled Identity. Englewood Cliffs, NJ, Prentice-Hall.

HERZFELD, Michael, 1980, "Honour and shame: problems in the comparative analysis of moral systems”, Man, 15 (2): 339-351.

HOCHSCHILD, Arlie Russell, 1979, "Emotion work, feeling rules and social structure”, American Journal of Sociology, 85 (3): 55 1-575.

JOBARD, Fabien, and Sophie NEVANEN, 2009, "Colour-tainted sentencing? Racial discrimination in court sentences concerning offences committed against police officers (19652005)", Revue Française de Sociologie, 50: 243-272.

KANE, Ousmane Oumar, 2011, The Homeland is the Arena: Religion, Transnationalism, and the Integration of Senegalese Immigrants in America. New York, Oxford University Press.

LAGRANGE, Hugues, and Marco OBERTI (eds.), 2006, Emeutes urbaines et protestations: Une singularité française. Paris, Presses de la Fondation Nationale des Sciences Politiques.

LEWIS, Helen B., 1971, Shame and Guilt in Neurosis. New York, International Universities Press. 
MARTIN, Daniel D., 2000, "Organizational approaches to shame: avowal, management, and contestation”, The Sociological Quarterly, 41 (1): 125-150.

PERISTIANY, Jean G. (ed.), 1965, Honour and Shame: The Values of Mediterranean Society. London, Weidenfeld and Nicolson.

PROBYN, Elspeth, 2004, "Everyday shame”, Cultural Studies, 18 (2-3): 328-349.

RYAN, Michael Timothy, 1993, "Shame and expressed emotion: a case study", Sociological Perspectives, 36 (2): 167-183.

SAYAD, Abdelmalek, 1979a, "Les enfants illégitimes (première partie)", Actes de la Recherche en Sciences Sociales, 25: 61-81.

SAYAD, Abdelmalek, 1979b, "Les enfants illégitimes (deuxième partie)", Actes de la Recherche en Sciences Sociales, 26: 117-132.

SAYAD, Abdelmalek, 2004, The Suffering of the Immigrant. Cambridge, Polity Press.

SCHEFF, Thomas J., 2000, "Shame and the social bond: a sociological theory", Sociological Theory, 18 (1): 84-99.

SCHWARTZ, Olivier, 1998, La notion de classes populaires. Saint Quentin-en-Yvelines, Université de Versailles, habilitation for research director, unpublished.

SUNDAR, Nandini, 2004, "Toward an anthropology of culpability", American Ethnologist, 31 (2): 145-163.

TIMERA, Mahamet, 2002, "Righteous or rebellious? Social trajectory of Sahelian youth in France", in D. Bryceson and U. Vuorela (eds.), The Transnational Family, New European Frontiers and Global Networks. Oxford and New York, Berg, 147-154. 